\title{
The implementation of energy subsidy reduction policy on the Indonesian economy performance
}

\author{
Rita Handayani ${ }^{1 *}$, Siro Juzilam ${ }^{2}$, Murni Daulay ${ }^{3}$, Dede Ruslan ${ }^{4}$ \\ Universitas Sumatera Utara, Medan, Indonesia ${ }^{1,2,3}$ \\ Universitas Negeri Medan, Medan, Indonesia ${ }^{4}$ \\ rita_handayani83@yahoo.co.id
}

Article History

Received on 28 April 2020

Revised on 3 June 2020

Accepted on 15 june 2020

\begin{abstract}
Purpose: This study aims to evaluate the impact of the implementation of the energy subsidy reduction policy conducted by the Government of Indonesia for the period 2015-2017. The author examines the application of the subsidy reduction policy and its impact on economic performance, specifically on economic growth; inflation rates, sectoral employment absorption, income levels and households group income distribution using the computable general equilibrium approach (CGE Model).
\end{abstract}

Research Methodology: The study used data from the 2008 Social Economic Balance System (SNSE) published by the Indonesian Central Statistics Agency (BPS). Furthermore, it also built a balance of data base with the static version 1.1 PEP model, version 2.0 making the energy subsidy reduction policy a shock in the simulation model developed.

Results: The author found that the application of policy to reduce energy subsidies has an impact on increasing economic growth, reducing inflation, increasing employment in the livestock, hospitality, land transportation and other service sectors.

Limitation: The limitation of this study is the use of funding 2008.

Contribution: The government as a stakeholder should provide the inclusive potential opportunity and considerable funds for research and development of new energy sources which will benefit of the future of nation's life.

How to cite: Handayani, R., Juzilam, S., Daulay, M., Ruslan, D. (2020) The implementation of energy subsidy reduction policy on the Indonesian economy performance. International Journal of Financial, Accounting, and Management, 1(4), 235-246.

\section{Introduction}

A state is deemed as a legitimate body that is obliged to generate prosperity for all elements of society. In the process of managing the state which goal is for the sake of achieving the welfare of society, the Government must implement strategies that synergize with high institutions in the financial sector to carry out fiscal and monetary policies. Fiscal policy is a policy which main authority is in the hands of the Government represented by the Ministry of Finance of the Republic of Indonesia. Based on Law No. 17 of 2003 concerning State finances, in which the President grants the authority to manage the finances and assets of the State to the Minister of Finance as the fiscal manager and the Government's representative in the ownership of the separated State assets. In carrying out its function in fiscal policy, the Government plays a role in collecting revenue and expenditure. Income accounts derived from state revenues, meanwhile, expenditure items which include national's expenditure. Adhering to the deficit system, the Indonesian APBN (state's budget) indicates a value of expenditure that is greater than its national's revenue which is considered to be one of the characteristics of a developing country. 
Table 1 Primary Balance, Balance of Payment and Financing Deficits Budget in IDR Trillion units

\begin{tabular}{|l|c|c|c|}
\hline & 2015 & 2016 & 2017 \\
\hline Primary Balance & $-142,4$ & $-88,2$ & $-109,0$ \\
\hline Deficit & $-222,5$ & $-273,2$ & $-330,2$ \\
\hline Budget Financing & 323,1 & 297,6 & 330,2 \\
\hline
\end{tabular}

Source: Data processed by APBN 2015-2017 Publication of the Indonesian Ministry of Finance

With a large deficit value, the Government must allocate channeling to productive economic activities that are needed by the community, especially those that have a multiplier effect on accelerating development and economic growth. The greater and heavier burden of the state budget deficit will somehow force the government to make a policy that is controversial and not so popular, which is by decreasing the amount of energy subsidies distributed to the public. Moreover, energy subsidies are considered expenditures that are consumptive and not on target because they are mostly savored by the middle and well-off class.

Table 2 Table of the Republic of Indonesia's Energy Subsidy Expenditure Policy in Trillion Rupiah Units

\begin{tabular}{|l|c|c|c|}
\hline \multicolumn{1}{|c|}{ EXPENDITURE } & 2015 & 2016 & 2017 \\
\hline Subsidies & 414,7 & 182,6 & 160,1 \\
\hline Energy subsidies & 344,7 & 102,1 & 77,3 \\
\hline Non-energy subsidies & 70,0 & 80,5 & 82,7 \\
\hline
\end{tabular}

Source: data processed by the 2015-2017 State Budget Publication of the Ministry of Finance

Energy subsidies are subsidizations given by the government to the community so that people will be able to pay energy expense which prices are below world rates. The biggest drop in subsidies was in the Energy Subsidy post, in 2015 Energy Subsidies were Rp344.7 T, down to Rp102.1T in 2016 and the lowest was in 2017 where Energy Subsidies were only Rp77.3 T. Total reduction in three years was reported 58 percent.

\subsection{Importance of the problem}

With the condition of world oil prices which is very volatile and influenced by the increasing population, the need for energy from year to year will also upsurge. An increase in population intensifies the heavy encumbrance of energy subsidies that must be spent on the APBN expenditure post each year. Based on the above point of view, the policy of implementing subsidy reduction results an interesting objective of research in this paper. This study provides an overview of the impact of the implementation of the Government's policy to reduce energy subsidies on economic growth, inflation rates, sectoral employment, household income and household income distribution using the general equilibrium model (CGE Model) analysis approach.

\section{Literature review}

Maipita et al (2010) in "The Impact of Fiscal Policy on Economic Performance and Poverty Rate in Indonesia" showed that measuring the impact of the Government's fiscal policy on income distribution and poverty rates in Indonesia by using the Computable General Equilibrium (CGE Model) model. The study applied simulations using variable taxes, subsidies and government spending that are injected into the economy to see the implications that occur in the economy after the shock is given.

The results of this study show the impact of increased subsidies is considerably better than the two previous fiscal policies i.e.on tax and government spending. Although income transfer policies have a positive impact on increasing rural household income and reducing poverty, on the other hand this policy has a negative impact on reducing GDP. 
Based on previous research, the Government's decision to implement a policy of gradual reduction in the allocation of expenditure for energy subsidies is contradictory, thus, it is necessary to carry on this research. It is by conducting simulations using the policy variable to reduce energy subsidies in order to explain the implications that occur in economic performance. Apart from that, it is also done by looking at the extent of the impact of fiscal policy that has been carried out on increasing economic growth, inflation rates, sectoral employment, income and income distribution of household groups in Indonesia. By giving a shock to the model, this research focuses on the impact of policies on reducing energy subsidies on the economy using the CGE Model approach.

\section{Research methods}

\subsection{Get to know the CGE model}

The Computable General Equilibrium Model (CGE model) is kown as a multisectoral general equilibrium model that can be computed. This is a class of economic models that employs actual economic data to estimate how the economic sector reacts to changes in external factors such as policy, technology and other factors.

The CGE model comprises equations that describe variables from a data base that are detailed and reliable with the equations in the model. Equations in the CGE model are generally based on neoclassical schools of economics which are often grounded on assumptions of minimization of production costs, pricing based on average production costs and maximization of utility by consumers, decisions to produce and consume, the behavior is explained nonlinearly, first order optimal conditions. Production and consumption decisions are derived from profit maximization and utility. This equation also includes the size of the constraints or limitations.

The data used in the CGE model is in the form of an input-output data base table or social accounting matrix. The CGE model database generally represents the economy of a country as a whole in a number of sectors, commodities, factors and types of households (consumers). The CGE model uses an elasticity approach, namely Constant Elasticity Subtitles (CES). CES shows the production manufactured by different countries can replace each other, and how household demand reacts to changes in income. The value of elasticity is a parameter that represents reactions in the economy. The CGE model is valuable for approximating the impact of changes that occur in one economic sector to other sectors.

The CGE model always has more variables than equations. Thus, the value of certain variables must be determined outside the (exogenous) model. Determination of exogeneous variables in a CGE model is called closure. Closing different models can give different simulation results. The CGE model is accommodating for representing the economies of countries where time series data is not available or not relevant for use (for example due to political changes). Therefore, the economies of developing countries are suitable to be studied with the CGE model.

The general equilibrium model was first developed by Walras (1874). Walras argues that all prices and quantities of goods in all markets are determined simultaneously through a process of interaction with one another. To find a general equilibrium point is not easy, but as Walras found that the balance does exist even though it has not been able to explain the existence of that balance and empirical evidence both concerning the uniqueness and the level of stability.

In explaining general equilibrium conditions, Walras uses a mathematical approach that is illustrated through the concept of excess demand A system consisting of n markets, has a demand $X^{D}{ }_{(P)}$, an offer function $X_{(P)}^{S}$, and an access demand function (excess demand) for the $\mathrm{j}$ market which is defined as:

$$
Z_{j}(P)=X_{j}^{D}-X_{j}^{S} \cdots \cdots(2.1)
$$


In equilibrium conditions, for each I-market simultaneously applies $X_{(P)}^{D}=X_{(P)}^{S}$ and conditions:

$$
\sum_{i=1}^{n} P_{j} \cdot Z_{j}=0, \text { where each } P_{j} \geq 0 \ldots
$$

In a market system, endowment vectors are defined as the basic ability of producers to create commodities that are consumed by consumers. Thus, the equation of excess demand $\mathrm{Z}(\mathrm{P})$ for the $\mathrm{j}$ market can be written as:

$$
\begin{aligned}
& Z_{j}(P)=\sum_{i=1}^{n} X_{i j}\left(P, P . e_{i}\right)-\sum_{i=1}^{n} e_{i j} \ldots \ldots \ldots . . . \\
& Z_{j}(P)=\sum_{i=1}^{n} X_{i j}\left(\text { P }, \text { P. } e_{i}\right)-\sum_{i=1}^{n} e_{i j} \ldots \ldots \ldots . .
\end{aligned}
$$

The law proposed by Walras is based on the supposition that in an economy consisting of $\mathrm{n}$ commodity markets, a state of equilibrium can be divided into two kinds, namely partial equilibrium and general equilibrium.

\subsection{Identity Subsection}

To assess the impact of policies on reducing energy subsidies on economic performance, specifically on economic growth, inflation, employment, income levels and distribution of household income in Indonesia, the Computable General Equilibrium model is used as the main analysis tool. The CGE model is comparative static, used to answer the research objectives by building, modifying and using a basic model derived from the CGE model PEP-1-1, static, version 2.0, May 2012 developed by Decaluwe et al., (2012), this development of the initial model has been conducted previously by Sukoco (2013) Indonesian version of SNSE data, then made adjustments according to the needs deemed necessary in developing models further.

\subsection{Social Accounting Matrix (SAM) or Social Economic Balance System (SNSE)}

According to Searle (1982) Social accounting matrix (SAM) or also known as the socioeconomic balance system (SNSE) is a traditional double input balance sheet economy in the form of a partition matrix that accounts all economic transactions between agents, especially between sectors within a block production; sectors within the institutional block (including households); and sectors within the factor production block in an economy (Hartono \& Resusudarmo, 2008).

SNSE is one of the data that meets the requirements of a CGE model, which covers almost all variables in a region's economy. SNSE is a good data collection system because (1) SNSE summarizes all economic transaction activities that occur in an economy for a certain period of time, SNSE can easily provide an overview of the economy of a region. (2) SNSE portrays the socioeconomic structure in the economy, thus the SNSE can provide an overview of the poverty and income distribution in the economy.

SNSE is a vital analysis tool because (1) analysis using SNSE can better show the impact of an economic policy on community conditions, or an economic policy can be seen its impact on poverty and income distribution, (2) analysis with SNSE is relatively simple, thus, its application can be carried out easily in various countries.

\subsection{Data types and sources}

The main data used to construct the CGE model basic data in the study are secondary data with national scope, namely: Indonesian Social Economic Balance System (SNSE) data for 2008 and the BPS National Socio Economic Survey (SUSENAS) in 2008 publication. Other main supporting data, 
among others, are the 175 Indonesian input-output (I-O) tables in 2005 and Indonesia's 66 inputoutput (I-O) tables in the 2008 BPS publication.

The data used consisted of 18 factors of production (16 factors of labor production, 2 factors of nonlabor production), 10 institutions ( 8 households and 2 other institutions) and 24 production sectors. Furthermore, there are also capital balance, indirect taxes, subsidies and foreign balance sheets.

In addition to the records above, to construct basic data and models, the coefficient of elasticity of several parameters is needed with a system of equations and other statistical data in the form of macro and sectoral data. Most of the data was obtained from the official publication of the Indonesian Central Statistics Agency (BPS). Meanwhile, parameter data and elasticity values will be taken from a number of previous research results that are considered relevant.

\subsection{Model Computation Results Validation}

Validation of model computational results is a condition that must be met before simulations are performed on the CGE model. Validation of results in the CGE model must meet 4 aspects of computing, namely: (1) the formation of initial SAM values through equations in the CGE model called SAM calibration results. (2) the number of iterations to produce a calibration SAM (beforeoptimality SAM) must be equal to zero. (3) a solution must be found (marked by the emergence of "EXIT-Solution Found or Normal Completation" when the program is run) for the usage of SAM initial values by all equations in the CGE model; and (4) the values resulting from the solution form the SAM (post-optimaly SAM) and the values must be exactly the same as the original SAM and must meet the balance requirements.

\section{Results and discussions}

Before the simulation results are presented, the following is a grouping of household versions of the SNSE data published by the Indonesian Central Statistics Agency.

Table 3: Types and Division of Households

\begin{tabular}{|l|l|}
\hline Agricultural laborers & hhd1 \\
\hline Agricultural entrepreneurs & hhd2 \\
\hline $\begin{array}{l}\text { Lower-class free entrepreneurs, administration staff, mobile traders, freelance } \\
\text { in the transportation sector, personal services, unskilled laborers, Rural }\end{array}$ & hhk1 \\
\hline Not a labor force and the vague class, Rural & hhk2 \\
\hline $\begin{array}{l}\text { Upper- class free enterpreneur, non-agricultural entrepreneurs, managers, } \\
\text { military, professionals, technicians, teachers, administration staffs and upper } \\
\text { class sales, Rural }\end{array}$ & hhk3 \\
\hline $\begin{array}{l}\text { Lower- class free entrepreneurs, administration staffs, mobile traders, } \\
\text { freelance in the transportation sector, personal services, unskilled laborers, } \\
\text { urban }\end{array}$ & hhk4 \\
\hline Not a labor force and the vague class, Urban & hhk5 \\
\hline $\begin{array}{l}\text { Upper-class free enterpreneurs, non-agricultural entrepreneurs, managers, } \\
\text { military, professionals, technicians, teachers, administration staffs and upper } \\
\text { class sales, Urban }\end{array}$ & hhk6 \\
\hline
\end{tabular}

\subsection{Economic growth and inflation rate}

The results of the simulation analysis and the implementation of the energy subsidy reduction policy carried out by the Government by decreasing gradually in 2015-2017 by 58 percent and its impact on economic performance can be seen in the results below. The policy of decreasing energy subsidies has an impact on increasing economic growth by 0.6 percent and reducing inflation by 0.02 percent

Table 4: Changes in Economic Growth and Inflation in SIM 2

\begin{tabular}{|l|l|l|}
\hline Economic Indicators & BeforeSimulation & $\begin{array}{l}\text { Delta Changes to SIM } \\
2\end{array}$ \\
\hline
\end{tabular}




\begin{tabular}{|l|l|l|}
\hline Economic Growth & $5.1 \%$ & Up 0.6\% \\
\hline Inflation rate & $5.28 \%$ & Down 0.02\% \\
\hline
\end{tabular}

Source: CGE Model, data processed, Rita 2019

\subsection{Absorption of sectoral labor}

The impact of the decreasing energy subsidies policy for 2015-2017 has an effect on increasing employment in the economic sector as shown in the table below:

Table 5: Changes in Labor Absorption on Simulation

\begin{tabular}{|c|c|c|c|}
\hline NO & Variable & $\begin{array}{l}\text { Initial Conditions } \\
\text { (Base Line) }\end{array}$ & $\begin{array}{l}\text { Change } \\
\text { Results after } \\
\text { SIM 1 }\end{array}$ \\
\hline 1 & Food Crop Agriculture & $3.56 \mathrm{E}+05$ & Up $3.50 \%$ \\
\hline 2 & Other Crop Agriculture & $1.06 \mathrm{E}+05$ & Up $1.06 \%$ \\
\hline 3 & Animal Husbandry and its Products & 91494.808 & Up $9.10 \%$ \\
\hline 4 & Forestry and Hunting & 15275.031 & Up $1.40 \%$ \\
\hline 5 & Fishery & 49457.058 & Up $4.90 \%$ \\
\hline 6 & Coal, Metal Ore and Petroleum Mining & 60074.86 & Up 5.99\% \\
\hline 7 & Mining and Other Excavations & 46746.213 & Up $4.63 \%$ \\
\hline 8 & Food, Beverage and Tobacco Industry & $1.20 \mathrm{E}+05$ & Up $1.23 \%$ \\
\hline 9 & $\begin{array}{l}\text { Spinning, Textile, Clothing and Leather } \\
\text { Industry }\end{array}$ & 45828.696 & Up $4.58 \%$ \\
\hline 10 & Wooden products \& Wood Industry & 35860.028 & Up $3.58 \%$ \\
\hline 11 & $\begin{array}{l}\text { Paper, Printing, Transport Equipment and } \\
\text { Metal and Industrial Products }\end{array}$ & $1.79 \mathrm{E}+05$ & Up $1.79 \%$ \\
\hline 12 & $\begin{array}{l}\text { Chemical Industry, Fertilizers, Clay } \\
\text { Products, Cement }\end{array}$ & $1.67 \mathrm{E}+05$ & Up $1.65 \%$ \\
\hline 13 & Electricity, Gas and Drinking Water & 16370.867 & Up $1.55 \%$ \\
\hline 14 & Construction & $2.01 \mathrm{E}+05$ & Up $1.99 \%$ \\
\hline 15 & Trading & $4.41 \mathrm{E}+05$ & Up $4.43 \%$ \\
\hline 16 & Restaurant & $1.04 \mathrm{E}+05$ & Up $1.05 \%$ \\
\hline 17 & Hospitality & 9278.8 & Up $9.36 \%$ \\
\hline 18 & Land Transportation & 87257.51 & Up $8.69 \%$ \\
\hline 19 & $\begin{array}{l}\text { Air, Water and Communication } \\
\text { Transportation }\end{array}$ & 68099.975 & Up $6.79 \%$ \\
\hline 20 & $\begin{array}{l}\text { Transportation Support Services, and } \\
\text { Warehousing }\end{array}$ & 20444.664 & Up $2.03 \%$ \\
\hline 21 & Bank and Insurance & 53145.725 & Up $5.30 \%$ \\
\hline 22 & Real Estate and Corporate Services & 45543.003 & Up $4.54 \%$ \\
\hline 23 & $\begin{array}{l}\text { Government and Defense, Education, } \\
\text { Health, Film and Other Social Services }\end{array}$ & $2.86 \mathrm{E}+05$ & Up $2.87 \%$ \\
\hline 24 & Personal, Household and Other Services & 86104.233 & Up $8.61 \%$ \\
\hline
\end{tabular}

Source: CGE Model, data processed, Rita 2019

The impact of the reducing subsidies policy has an effect on increasing employment of some economic sectors, with the highest of 9-8 percent occurring in the hotel sector, the live stock sector, the land transportation sector and other service sectors. Furthermore, the sectors that experienced a moderate increase of 6-4 percent were the water transportation sector, mining sector, banking sector, fisheries sector, textile industry sector, trade and real estate sector. The last ten sectors are the weakest ability to absorb labor (can be seen in the table above).

\subsection{Income and distribution of household income groups}

The impact of decreasing energy subsidy policy on income and income distribution of household groups presented as in the table below: 
Table 6 Changes in the Distribution of Household Income in the Impact of Simulation 2

\begin{tabular}{|l|l|l|l|l|}
\hline NO & Variabel & $\begin{array}{l}\text { Initial } \\
\text { Conditions } \\
\text { (Base Line) }\end{array}$ & $\begin{array}{l}\text { Results of } \\
\text { Changes } \\
\text { in Income } \\
\text { after } \\
\text { Simulatio } \\
\text { n }\end{array}$ & $\begin{array}{l}\text { Changes in } \\
\text { Income } \\
\text { Distributio } \\
\text { n After } \\
\text { Simulation }\end{array}$ \\
\hline 1 & Agriculture Workers & $1.77 \mathrm{E}+05$ & Up1.78\% & Up 0.01\% \\
\hline 2 & Agriculture entrepreneurs & $7.32 \mathrm{E}+05$ & Up7.39\% & Up 0.07\% \\
\hline 3 & $\begin{array}{l}\text { Lower-class free entrepreneurs, administration staffs, } \\
\text { mobile traders, freelance in the transportation sector, } \\
\text { personal services, unskilled laborers, Rural }\end{array}$ & $4.94 \mathrm{E}+05$ & Up4.95\% & Up 0.01\% \\
\hline 4 & $\begin{array}{l}\text { Not the labor force and the vague class, Rural } \\
\text { Upper-class free entrepreneurs, non-agricultural } \\
\text { entrepreneurs, managers, military, professionals, } \\
\text { technicians, teachers, administration staffs, and upper } \\
\text { class sales, Rural }\end{array}$ & $1.73 \mathrm{E}+05$ & Up1.74\% & Up 0.01\% \\
\hline 5 & $\begin{array}{l}\text { Lower-class free entrepreneurs, administration staffs, } \\
\text { mobile traders, freelance in the transportation sector, } \\
\text { personal services, unskilled laborers, urban areas }\end{array}$ & $7.68 \mathrm{E}+05$ & Up4.71\% & Up 0.03\% \\
\hline 7 & $\begin{array}{l}\text { Not a labor force and the vague group, Urban } \\
\text { Upper-class free entrepreneurs, non-agricultural } \\
\text { entrepreneurs, managers, military, professionals, } \\
\text { technicians, teachers, administration staffs and upper } \\
\text { class sales, Urban }\end{array}$ & $2.44 \mathrm{E}+05$ & Up2.44\% & $\begin{array}{c}\text { Fixed } \\
0.00 \%\end{array}$ \\
\hline 8 & $\begin{array}{l}\text { Und } \\
0.03 \%\end{array}$ & \\
\hline
\end{tabular}

Source: CGE Model, data processed, Rita 2019

The implementation of the government's energy subsidy reduction policy has the highest impact on changes in household income of the household group, upper class free entrepreneurs, non-agricultural entrepreneurs, managers, military, professionals, technicians, teachers, administration staffs and upper class sales, Urban, household groups and Agriculture entrepreneurs.

The last variable is the impact of the implementation of the reducing energy subsidies policy on income distribution; the group which experiences the highest impact of the decline in income distribution is the lower-class free entrepreneurs, administration staffs, mobile traders, freelance in transportation sector, personal services, unskilled laborers, urban and non-labor force, vague classsnd urban. These two groups of households are the middle and poor class of households living in the city and experience the most impact from the implementation of policie scarried out by the Government.

\section{Conclusion}

The conclusion from the simulation results of the impact of the implementation of the reducing subsidies policy on economic performance is an increase in economic growth of 0.6 percent and lower inflation by 0.02 percent. Apart from that, there is an increased on employment absorption with the highest of 9-8 percent in the hotel sector, the livestock sector, land transportation sector and other service sectors. The highest income increase is experienced by the two groups of wealthy urban households and agricultural entrepreneurs. The highest decrease in income distribution occurred in middle and poor households in urban areas.

The policy implemented by the government also resulted in the increase of domestic energy prices in which all citizens must pay more for the energy they consume. This should be considered as a lesson for making another decision particularly in policy implementation for example by calculating the impact that might arise on the economy. This step becomes vital aspect. The reducing energy subsidies policy is also deemed as controversial and full of political overtones. People's representatives usually argue extensively when the policy is implemented because they try to ponder 
and protect the interest of lower classes who are most affected by this policy. This will not only have an impact on household income but also have an impact macroeconomic stability.

These conditions are in accordance with research conducted by Maipita (2010) for the case of Indonesia, which explains that the impact of increased subsidies is better than the two previous fiscal policies namely tax and government spending. Although the income transfer (subsidy) policy has a positive impact on increasing household income in rural areas and reducing poverty, another aspect to be taken as a consideration is that the policy has a negative impact on reducing GDP. The difference is that the reserachers used the subsidy reduction variable and looks at its impact on the income and income distribution of the urban poor.

\subsection{Policy mechanism for reducing energy subsidies}

When the government implements a policy of reducing energy subsidies, domestic energy prices will escalate, resulting in lower disposable income because people must pay more for new energy prices after reducing subsidies. This condition has an impact on reducing consumption which will ultimately reduce national income. Conversely, when the Government increases energy subsidies, energy prices will plummet, further affecting the increase in disposable income as well as increasing consumption which will ultimately upsurge national income.

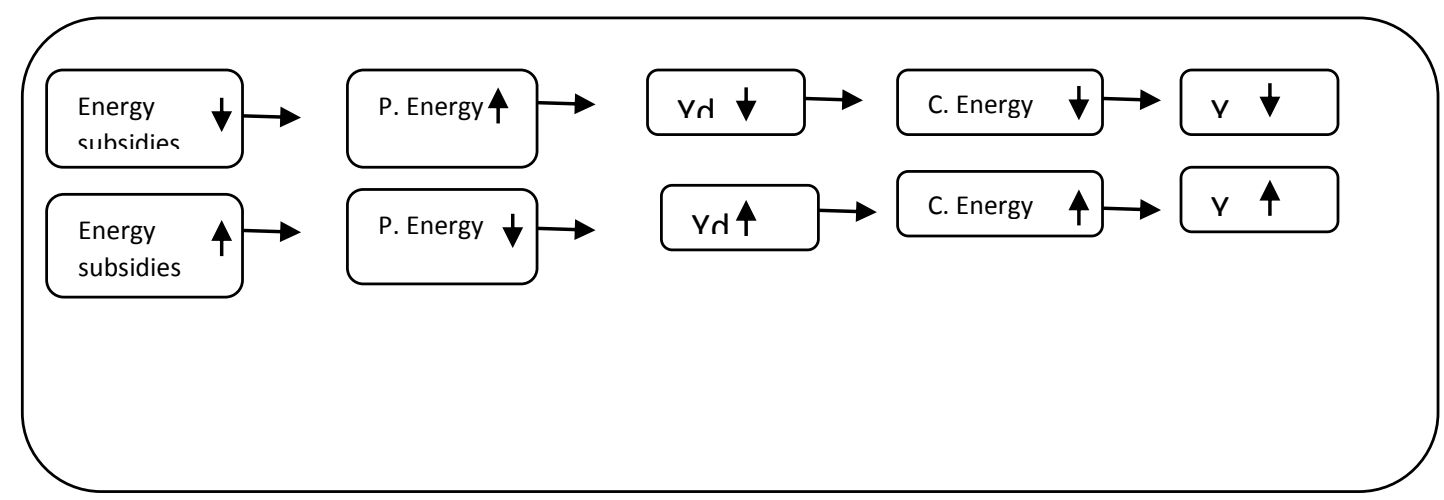

Figure 5.3: Policy Mechanism for Reducing Energy Subsidies

In theory, the decline in energy subsidies by the Government will have an impact on rising prices. It is because energy is a production input, a decrease in energy subsidies or an increase in domestic energy prices will generally have an effect on rising prices or driving up the cost or supply side inflation. Energy subsidies are financial assistance provided by the Government with the aim of maintaining or increasing people's purchasing power on energy and increasing people's ability to consume energy by selling energy prices below world prices.

Energy is a component of production costs and a rising energy price which is the effect of decreasing energy subsidies will have an impact on rising production costs. The heaviest impact of reducing energy subsidies or increasing fuel prices is inflation, because fuel is one of the factors of production costs, thus, an increase in fuel prices will raise the price level and ultimately drive inflation on the supply side.

As one of the components of production costs, the reduction in energy subsidies will result in sluggish economic conditions, the impact of cost push inflation or an increase in inflation. The decline might not be significant because energy is an average element, the reduction in energy consumption which is the effect from incresead price will not last long. As soon as the society adjusts to new price for energy consumption, economic conditions will eventually form a new balance.

\subsection{Reducing the budget deficit}

Government's policy in reducing energy subsidies is an effort to reduce the government's expenditure burden; subsidies are one of the features on the APBN (national expenditure Budget). The amount of energy subsidy quota needed will be in line with the increase in the amount of energy demand, one of which is caused by an increase in the population. The increase in population will surge energy needs, 
and the total value of subsidies that must be prepared and distributed by the Government will continue to increase in value from year to year.

Because the allocation of the amount of the subsidy is an expense burden on the state budget, the higher the expenditure spent by the government for subsidies will progressively burden the state budget and have an impact on the budget deficit. On the other hand, the energy needed in Indonesia is more from the imports. Therefore, the energy price is strongly influenced by fluctuations in energy prices in the world market as well as the exchange rate. This condition will be an additional burden on the state budget especially if there is an increase in world oil prices or the Middle East crisis.

\subsection{Energy subsidy allocation for the more entitled group}

Simulation results on the model shows that the policy of reducing energy subsidies has the most impact and burden experienced by the middle and poor households in urban areas. Meanwhile, in terms of income, the aforementioned two groups of households are relatively small which means it is not experiencing an increase in income compared to the group of well off households. This condition can be interpreted that the increase in energy prices was felt by poor households but did not affect the well off households. This can be interpreted that reducing energy subsidies is burdensome and has an impact on lower class communities. Because the poorest people will be experiencing the most impact of rising energy prices. In fact, they are also undeniably the largest household group of the total population of Indonesia. It means that the policy of removing subsidies is controversial and its political nuances are even unpopular.

The government has always claimed that energy subsidies have not been well targeted and delighted more by the middle class and wealthy. Thus, the policy of reducing energy subsidies currently being carried out by the Government is an effort to allocate subsidies to household groups that are more entitled and more poverty-stricken. The government must in fact continue to strive to realize a sense of justice in the community and must also be concerned that the policy will greatly affect the imposition of energy prices. This is not in accordance with the ability and level of welfare of the people. This condition will lead to a broad impact on other macroeconomics. Energy has always been known to be a vital factor of production and primary goods for the whole community, thus, policies related to the management and distribution of subsidies often become policies that are not populist and politically nuanced.

\section{4 Development of Alternative Energy Resources}

Indonesia is a country that has a rich and diverse amount of energy sources. Apart from the fossil energy sources that cannot be renewed in the form of oil and coal, Indonesia also has abundant alternative energy sources generated from sunlight, water, wind, plants, natural gas, geothermal and others. However, dependence on fossil fuel oil as the main energy source is undoubtedly high. As a matter of fact, fossil fuel energy is very limited in number and can be out of sources.

The increase in the number of population has also resulted in the need for energy. This pattern also continues to increase from year to year. An uncontrolled increase can actually become a boomerang especially if we cannot skimp on energy use. This is coupled with the amount of energy imports that we do to meet energy needs; it will have an impact on economic losses and the welfare of the people at large. The public will be burdened by the rising energy prices due to the oil crisis that hit the world and has an impact on oil price fluctuations, as well as foreign exchange conditions that are burdened by the impact of imports made.

The massive use of fossil fuels results in environmental damage on earth. Air pollution by industrial machinery and motor vehicles in the form of high exhaust gas energy also impacts on human health. Other bearings include the variety of chronic diseases caused by air pollution and thin ozone layer due to the greenhouse effect. The costs incurred by society from the consumption of these fossil energy sources are massive and somewhat uncontrolled. Therefore, there is an urgency of the new presence of alternative energy sources that are environmentally friendly as well as renewable.

There are so many alternative energy sources that can be utilized for the benefit of human life, such as sunlight, wind, methane gas utilization from organic waste and impurities in the form of biomass, 
vegetable oil and others. Unfortunately the use of alternative energy is still not popular in the community. There are still many people who are reluctant and unwilling to be complicated to get alternative energy sources. Society prefers to buy practical fuel as a source of energy for it is quite cheap and pragmatic.

When thinking far ahead, the management of alternative energy resources has offered enormous benefits for humans. Alternative energy sources have much compensation including its characteristcs to be unlimited, economical, efficient, environmentally friendly and renewable. It is also time for us to think about preparing the better lives of future generations with proper education, counseling, guidance and cooperation from all parties particularly in the spectrum of development and application of alternative energy sources. The government as a stakeholder should provide the inclusive potential opportunity and considerable funds for research and development of new energy sources which will benefit of the future of nation's life.

\section{Limitation and study forward}

The limitation of this study is the use of funding 2008, the updated data published by the Indonesian Central Statistics Agency (BPS) is very important because it can describe the real economic conditions. Expansion can also be done in further studies by selecting other variables so that they can explain macroeconomic conditions further.

\section{Acknowledgement}

Thank you to all people who have helped from the beginning phase of the research process to the completion of this paper. I would like to thank the following people for helping me finalise the project; Dr. Djoni Hartono and Dr. Sukoco from the Universitas Indonesia, who particularly have assisted in the development of the basic model and shock formulation as well as reading the simulation results in research.

\section{References}

BPS. (2005). Tabel input output (i-o) indonesia 2008. Badan Pusat Statistika Indonesia.

BPS. (2008) Sistem neraca sosial ekonomi (SNSE) Indonesia 2008. Badan Pusat Statistika Indonesia.

BPS. (2008). Sistem Neraca Sosial Ekonomi Indonesia Tahun. Badan Pusat Statistik, JakartaIndonesia.

David Romer. (2000). Keynesian macroeconomics without the LM Curve. Journal of Economic Perspectives, 14(2).

David Romer. (2006). Advance macroeconomics. The McGrow - Hill Companies, Inc. San Juan Singapore Sydney Tokyo Toronto.

Dornbusch, Rudiger \& Stanley Fischer, J Mulyadi(ed). (1996). Makroekonomi. Penerbit Erlangga: Jakarta.

Decaluwe, Bernard., Lemelin, Andre., Maisonnave, Helene., \& Robichaud, Veronique. (2012). The PEP standard computation general equilibrium model: Single-country, static version.

Hartono, D., Resosudarmo, P. (2008). Dampak ekonomi keseluruhan dari mengendalikan konsumsi energi di Indonesia: Analisis menggunakan kerangka kerja matriks akuntansi sosial. Jurnal Kebijakan Energi.

Maipita, Indra., Jantan, Mohd., \& Abdul-Razak, Nor. (2010). Dampak kebijakan fiskal terhadap kinerja ekonomi dan angka kemiskinan di Indonesia. Buletin Ekonomi Moneter dan Perbankan.

Searle, S. R. (1982). Matrix algebra useful for statistics. John Wiley and Sons. New York.

Sukoco. (2013). Analisis dampak liberalisasi dan fasilitas perdagangan terhadap kinerja perekonomia, kemiskinan dan ketimpangan distribusi pendapatan. Disertasi Doktor (tidak dipublikasikan), Depok, Program Pasca Sarjan, Universitas Indonesia.

Gregory Mankiw. (2008). Makroekonomi, Edisi keenam. Penerbit Erlangga: Jakarta. 
Oktaviani, R. (2011). Model ekonomi keseimbangan umum, teori dan aplikasinya di Indonesia. PT. Penerbit IPB Press.

Bappenas. Laporan hasil kajian penyusunan model perencanaan lintas wilayah dan lintas sektor, pengembangan model CGE. Direktorat Kewilayahan I, Bappenas

Wardhana, W., Hartono, Djoni. (2012). Instrument stimulus fiskal: Pilihan kebijakan dan pengaruhnya terhadap perekonomian. Jurnal Ekonomi Pembangunan Indonesia, 12(2).

Walras, L. (1874). Elements d'economie politique pure. Lausanne: L. Corbaz. Transl. by William Jaffe as elements of pure economics, Homewood, Ill.: Richard D. Irwin. (1954).

\section{Appendix A}

1. Calibration Results of SAM

Input file: C:IUserlUser|DocumentsISAM BALANCE Tahap1\SAM-V2.xls

Output file: C:IUser|User|DocumentsISAM BALANCE Tahap1ISAM-V2.gdx

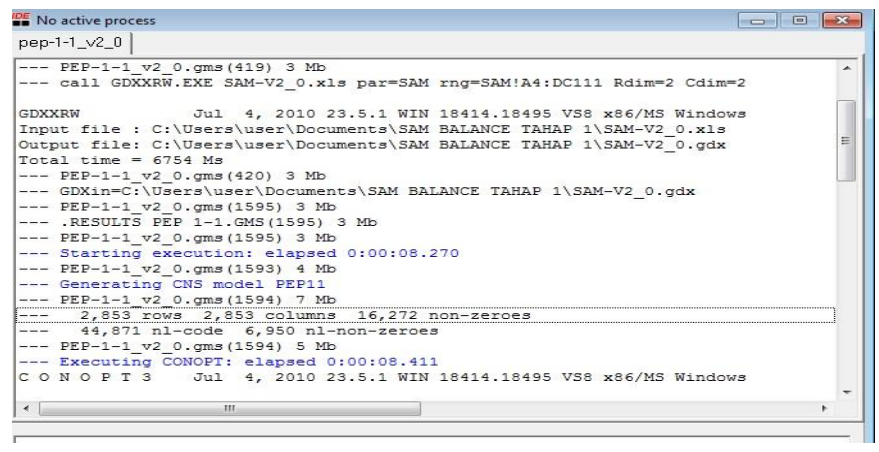

2.Number of Iterations to produce a calibration SAM(before-optimality SAM).

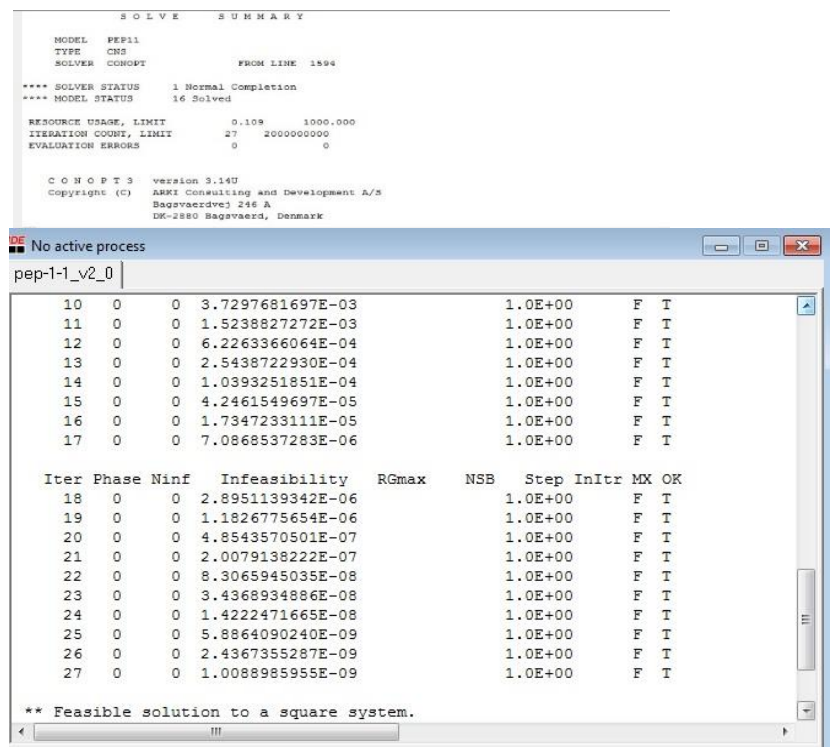


2. Normal Condition of Complation

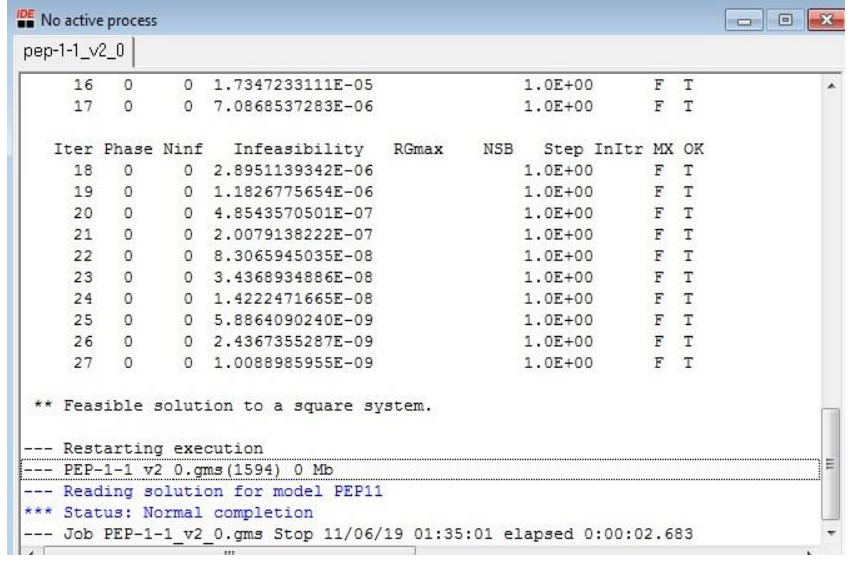

The values resulting from the solution form the SAM equation (post-optimally) 